\title{
Anatomy of two Rhododendron species along the elevational gradient, Eastern Nepal
}

\author{
M. L. Pathak ${ }^{1,4^{*}}$, B. B. Shrestha ${ }^{2}$, L. Joshi ${ }^{3}$, X. F. Gao ${ }^{4}$ and P. K. Jha ${ }^{2}$
}

\begin{abstract}
A wide range of habitat conditions including elevation determine adaptative variation in a species. The study was carried out to investigate the anatomical variation of two common species of Rhododendron ( $R$. anthopogon and $R$. lepidotum) growing between 3200 and 4700 m asl in Gokyo valley of Sagarmatha National Park, Khumbu, eastern Nepal. Seven anatomical characters viz. pore area (PA), pore density (PD), vessel element length (VEL), fiber tracheid length ( $F L)$, ray density $(R D)$, uniseriate ray height (URH) and uniseriate ray cell number (URCN) of twenty-three samples for two species (12 samples of $R$. anthopogon and 11 of $R$. lepidotum) were studied by making permanent slides of transverse, tangential longitudinal and radial longitudinal stem sections. In $R$. anthopogon, out of three non- anatomical characters (plant height, soil nitrogen and leaf nitrogen) the nitrogen content in leaf increased with increasing elevation. However, the plant height and nitrogen content in soil did not vary significantly with elevation. Out of the seven wood anatomical characters three characters such as PA, VEL and FL decreased with increasing elevation. The other four characters, PD, RD, URH and URCN did not vary significantly with elevation. In $R$. lepidotum, plant height decreased with increasing elevation and nitrogen content of soil and leaf increased with elevation. The PD, PA, VEL and FL decreased along the elevation gradient. However, RD, URH and URCN did not vary significantly with elevation. These variations in the anatomical features of both species have been attributed to the adaptative strategies of the plant in the hostile environment at high elevation.
\end{abstract}

Key words: Adaptation, ecological anatomy, elevation, Nepal, Rhododendron

$R$ hododendron (Ericaceae) is a large genus of woody plants and consists of c. 1000 species divided into eight sub-genera (Chamberlain et al., 1996). In Nepal, 31 species of Rhododendron are distributed in the montane to the alpine zones near to the vegetation limit (Rajbhandari and Watson, 2005), from the subtropical region ( $R$. arboreum) to the nival region ( $R$. nivale). Most species have an altitudinal range of $1000 \mathrm{~m}$, usually corresponding to a vegetation zone and four species R. lepidotum, $R$. anthopogon, $R$. arboreum, and $R$. setosum are distributed in an altitudinal range of 2000-3000 m, covering more than one vegetation zone (Noshiro and Suzuki, 1989). Among them, R. arboreum is found as low belt rhododendron (1200 $\mathrm{m}$ in Western Nepal), while $R$. nivale is reported from the tundra region at the vegetation limit $(5600 \mathrm{~m})$.

When considering the elevation gradients, it is useful to remember that, elevation by itself is not an environmental factor for the change in vegetation pattern and even anatomy of individual plant species (Keer, 2001). The change in anatomical characters also depends on the size of plant and elevation (Liang et al., 1993). However, elevation is the proxy terms for the numerous variables that change with elevation in different ways (Bass et al., 1983; Noshiro and Bass 1998; 2000). Thus, the present study is focused on the structural and functional trade-offs in stem anatomical characters of the plant (pores,

\footnotetext{
National Herbarium and Plant Laboratories, Godawari, Lalitpur, *Email: youngecologist@gmail.com

Central Department of Botany, Tribhuvan University, Kirtipur, Kathmandu

Tahachal, Kathmandu

Chengdu Institute of Biology, Chinese Academy of Sciences, Postal Code 610041, Chengdu, Sichuan, China
} 
vessels, fibers, rays, etc) and their quantitative and qualitative analysis along the elevation gradient.

Soil water is the most limiting ecological resource responsible for the distribution of higher plants. The degree of water stress in plants is controlled by the relative rate of water absorption and water deficit (Farquhar et al., 1989). It may be caused either by lack of available soil moisture or too slow absorption or too rapid loss of water, or most often by a combination of all three. The decline in tissue moisture content is due to lower resistance to withdrawal of water from turgid plant tissue than to uptake through the root (Kramer and Kozlowski, 1979). Plants, which can save water, must have a number of characteristics such as, less negative osmotic potential, more rigid cell walls, narrow xylem vessels capable of embolism prevention in severe drought and strong stomatal control to minimize water loss through transpiration (Levitt, 1972).

In this context, we have tried to analyze the variation in stem anatomical features according to the elevational range in two Rhododendron species to investigate the possible adaptative strategies by wood parameters along elevation gradient in different ecological aspects. For this we hypothesized that, along the elevation gradient plants change the shape, size and function of wood parameters to adjust or adopt on their exiting environment.

\section{Materials and methods}

After getting the permission from concerned authorities, stem samples of the two Rhododendron species were collected in 2008 from Gokyo valley of Sagarmatha National Park (SNP), eastern Nepal (Fig. 1). Lying in the Central Himalayas, the SNP encompasses the southern half of Mount Everest. The area was gazetted as National Park in July 19, 1976 and listed as a World Heritage Site in 1979 by The United Nations Educational Scientific and Cultural Organisation (UNESCO).

\section{Study area}

\section{Climate}

The climate of SNP area is semi-arid, with seasonal monsoon rains during some $56 \%$ of the past years, and a temperate dry season which has occurred twice in a year for $35 \%$ of the past years (Joshi, 1982). On an average, $80 \%$ of the annual precipitation falls between June and September. The remaining months of the year are moderately dry. Fires are hazard in spring. Precipitation is low as the park is in the rain shadow of the Karyalung-Kangtega range to the south, $733 \mathrm{~mm}$ in Khumjung, $984 \mathrm{~mm}$ in Namche Bazar, and $1043 \mathrm{~mm}$ in Thyangboche; but the Tibetan side of the mountains in the rain shadow of the crest is almost like desert. Winters are very cold. The mean temperature lowers up to $-0.4^{\circ} \mathrm{C}$ and there are occasional heavy snowfalls (Garratt, 1981).

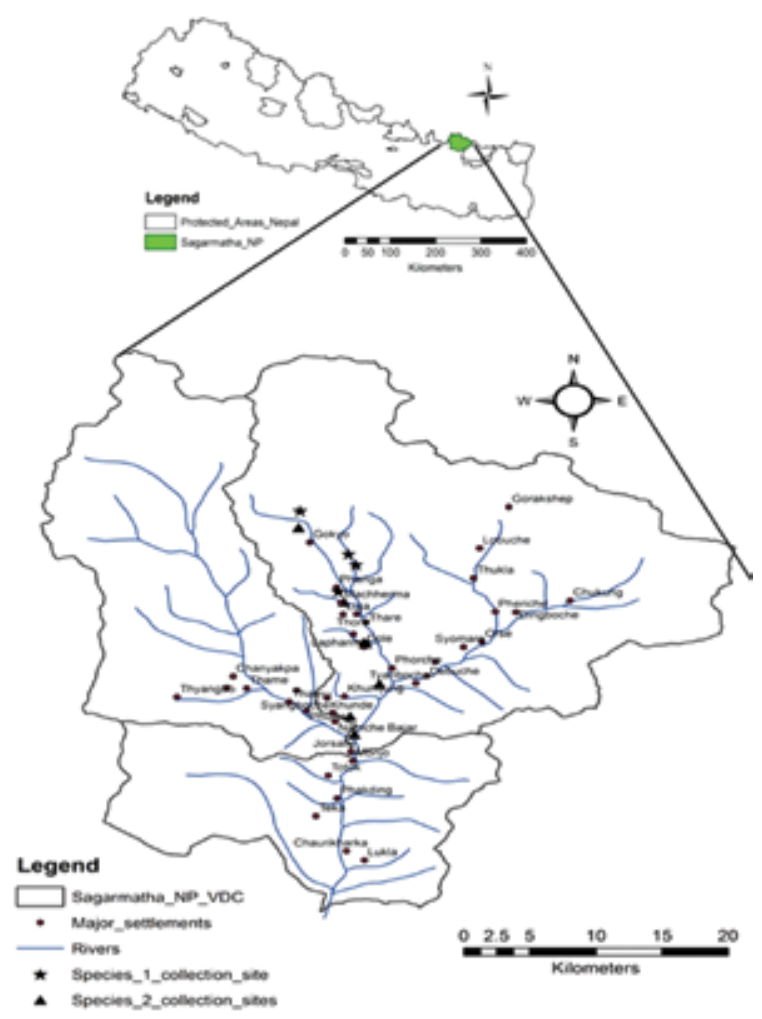

Fig. 1: Map showing the study area (Where species $1=R$. anthopogon and species $2=R$. Lepidotum)

\section{Rhododendron species in SNP}

The flora in the park includes 160 species of flowering plants (Bhuju et al., 2007). The park and the buffer zone consist of the following major vegetation zones: temperate mixed forest, lower and upper sub-alpine forest, lower and upper alpine zone, and sub-nival, and nival zone (Jha, 2010). There are fourteen species of Rhododendron in the SNP and its buffer zone (Shrestha and Jha, 2010), which are $R$. anthopogon, $R$. arboreum, $R$. barbatum, $R$. campanulatum, $R$. campylocarpum, 
$R$. cinnabarinum, $R$. dalhousiae, $R$. hodgsonii, $R$. lepidotum, $R$. lindleyi, $R$. nivale, $R$. setosum, $R$. triflorum and $R$. wallichii. Among them, nine species ( $R$. anthopogon, $R$. arboreum, $R$. campanulatum, $R$. lepidotum, $R$. nivale, $R$. setosum, $R$. campylocarpum, $R$. barbatum and $R$. triflorum) were recorded in the Gokyo valley.

\section{Study species}

Out of nine species recorded in the Gokyo valley of the SNP, two widely distributed species $R$. lepidotum and $R$. anthopogon were selected for the study.

\section{Rhododendron lepidotum Wall. ex G. Don.}

$R$. lepidotum locally called 'Bhale Sunpati' is a resinous shrub up to $1 \mathrm{~m}$ or more with pink, dull purple or pale yellow flowers. It has the widest altitudinal range of distribution of all Rhododendron species (2300-4700 m asl) in the study area. It prefers sloping and open terrain with bushes of various plants in the temperate forest and high elevation pastures. Except the $R$. setosum and $R$. anthopogon, it is associated with the mountain bushes such as Potentialla species, Clematis species, etc. Blooming of this species occurs from mid May to July.

\section{Rhododendron anthopogon D. Don.}

$R$. anthopogon locally called 'Sunpati' is a strongly aromatic small shrub up to $60 \mathrm{~cm}$ with 4-6 white or yellowish translucent petals in a cluster. $R$. anthopogon is the most common species of all Rhododendron species in the alpine region of the SNP. This species was common in the Gokyo valley and was found from the Dole to Gokyo lake system. It grows on rocky and grassy mountainous terrain frequently associated with $R$. setosum on alpine meadows. It blooms from mid May to July.

\section{Stem samples and measurements}

Stem samples of $R$. lepidotum and $R$. anthopogon were collected from the SNP, eastern Nepal at an altitude of 3200 to $4700 \mathrm{~m}$ asl. Though, these species are found both in the Gokyo and Khumbu valley of the SNP (Shrestha and Jha, 2010). The collection of stem samples was limited to NamcheGokyo region. Sampling was done along the trekking route at an elevation difference of about $200 \mathrm{~m}$ asl between Namche and Gokyo valley. At some places the elevation difference between successive sampling sites was up to $400 \mathrm{~m}$ asl due to physical inaccessibility. A total of 11 samples of $R$. lepidotum and 12 samples of $R$. anthopogon were collected. In some sites, the plants were grown in the rock, so the number of soil samples and leaf varied. Three samples were collected from each sampling site for each species. The internodes of the main stem above the base were collected in polythene bag separately for each sample and were brought to the laboratory. The stem samples were preserved in Formalin Acetic Acid (FAA) alcohol solution for two weeks. To make it friendly, the samples were transferred to $70 \%$ alcohol before starting work in laboratory. Thin microtome sections of $25 \mu \mathrm{m}$ thickness were prepared. For vessel element and fiber-tracheid length, the stem samples were cut longitudinally into thin pieces using blade and were kept in the solution of nitric acid (10\%) and chromic acid (10\%) for 24-48 hours to macerate. When the small pieces of wood samples were dissolved in the solution, length of vessel elements (VEL) and fibers (FL) were measured in temporary slides under compound light microscope. The seven wood parameters (PA, PD, VEL, FL, RD, URH and URCN) were measured using a calibrated ocular micrometer (Annex 1). For each parameter, 20-25 elements were measured for each sample; and their means and SD have been presented.

\section{Collection of soil and leaf samples}

Soil samples were collected from near the base of the same individual plant from which stem samples were collected. At each sampling site, three sub-samples of soil were collected from 30 $\mathrm{cm}$ depth, and they were mixed to make single sample (200 gm). Corresponding to the stem samples, there were 23 soil samples (11 samples from below the canopy of $R$. lepidotum and 12 from $R$. anthopogon). The samples were air dried in shade for one week and packed in air tight plastic bags (zipper plastic) until laboratory analysis.

Samples of leaves were collected from main twigs of the plant from which the stem samples were collected. Altogether, 20 leaf samples of $R$. anthopogon and $R$. lepodotum each were collected. Leaf samples were collected for leaf 
nitrogen content in leaf. In some sites, the plants were grown in the rock, so the number of samples of soil and leaves varied. Leaves were dried by placing between newspapers in the field and were brought to the laboratory.

\section{Analysis of nitrogen content in soil and leaf}

Nitrogen content of the collected soil and leaf samples were analyzed using micro Kjeldahl method (Gupta, 2000). The soil analysis methods included the Digestion, Distillation and Titration steps.

The same process as in the soil analysis was repeated to estimate the nitrogen content of leaves, 0.25 gram of leaf was taken for each sample. The chemicals used for leaf nitrogen were the same except the small amount of selenium powder $(0.25 \mathrm{gm})$ as catalyst. Total nitrogen content $(\mathrm{N}$ $\%)$ was calculated.

\section{Data analysis}

Results of all individuals were compared in relation to different non-anatomical factors (elevation, stem diameter and plant height). Correlation coefficients among these three factors and seven wood anatomical characters (pore area, pore density, vessel element length, fiber length, ray density, uniseriate ray height, number of cells in uniseriate ray and nitrogen content in soil and in leaf) were determined. Non anatomical and anatomical characters (plant height, nitrogen content in soil and leaf, pore area, pore density, vessel element length, fiber tracheid length, ray density, uniseriate ray height and uniseriate ray cell number) were then analyzed by simple linear regression. Analysis was done separately for two species. Mean values of all anatomical characters between two species were compared by independent sample t-test. These stastistical analyses were done using Statistical Package for Social Sciences (SPSS ver. 11.5). Coefficient of variation ( $\mathrm{CV} \%)$ was calculated using the formula $=\mathrm{SD} \times 100 /$ mean. The average air temperature and precipitation of the study year were noted down. These data were extracted from Climatology Resource for Agro climatology which covers a grid of $1^{\circ}$ latitude by $1^{\circ}$ longitude (https://power.larc.nasa.gov/cgi-bin/cgiwrap/ solar/agro.cgi; retrieved on $25^{\text {th }}$ September, 2017)

\section{Results and discussion}

\section{General anatomical features}

Stem anatomical features of $R$. anthopogon and $R$. lepidotum were fundamentally similar in transverse section. Cuticle was conspicuous in both species. Epidermis was one cell thick. Cortex was not distinguishable. Pericycle was narrow, made up of small sclerenchymatous cells and irregular in shape. Phloem consisted of very small elements but xylem was found wide in relation to the total diameter of the stem in both species. Pith was heterogeneous with different cell size and composed of parenchyma cells. Parenchyama cells of pith were larger in $R$. lepidotum than in $R$. anthopogon. The annual rings were distinct in $R$. lepidotum than in $R$. anthopogon (Plate 1A and 2A, Annex 2) and the mean number of annual rings was five in $R$. lepidotum but the ring was not clear in all samples of $R$. anthopogon. Crystals in parenchymatous pith were more common in $R$. anthopogon (Plate 1B, Annex 2) than in $R$. lepidotum (Plate 2B, Annex 2). Both uniseriate and multiseriate rays were found in the secondary xylem. In $R$. lepidotum, uniseriate rays were more common than multiseriate rays (Plate 2C, Annex 2), the cells in the rays were heterogeneous; some of them were round and others narrow and elongated (Plate 1C and 2C, Annex 2). Multiseriate rays were common in $R$. anthopogon (Plate 1D, Annex 2). Thickening of vessels was found scalariform in both species. The number of rays and number of cells in uniseriate ray were higher in $R$. anthopogon than in R. lepidotum (Table 1).

The mean vessel element length (VEL) was 260 $\mu \mathrm{m}$ in $R$. lepidotum and $268 \mu \mathrm{m}$ in $R$. anthopogon. For both parameters (VEL and FL), the coefficient of variation was higher in $R$. lepidotum than in $R$. anhopogon (Table 1). A larger variation in both VEL and FL of $R$. lepidotum could be related to wider elevation range of sampling sites, which ranged from 3200 to $4700 \mathrm{~m}$ asl for $R$. lepidotum and 4100 to $4900 \mathrm{~m}$ asl for $R$. anthopogon.

\section{Variation in wood anatomical features}

Mean pore density was quite higher in $R$. anthopogon than in R. lepidotum (Table 1), and their difference was not significant at $5 \%$ level (Table 2). Mean pore area was higher in $R$. lepidotum 
Table 1: Measurements of all anatomical characters of both species (CV: coefficient of variation)

\begin{tabular}{|l|l|l|l|l|}
\hline \multirow{2}{*}{ Parameters } & \multicolumn{2}{c|}{ Rhododendron anthopogon } & \multicolumn{2}{c|}{ Rhododendron lepidotum } \\
\cline { 2 - 5 } & \multicolumn{1}{|c|}{ Range } & \multicolumn{1}{c|}{ Mean $(\mathrm{CV})$} & \multicolumn{1}{c|}{ Range } & \multicolumn{1}{c|}{ Mean $(\mathrm{CV})$} \\
\hline Pore density $\left(\right.$ per $\left.\mathrm{mm}^{2}\right)$ & $135-200$ & $161(15.43)$ & $109-174$ & $143(14.18)$ \\
\hline Pore area $\left(\mu \mathrm{m}^{2}\right)$ & $320-509$ & $417(14.00)$ & $400 .-465$. & $429(4.54)$ \\
\hline VEL $(\mu \mathrm{m})$ & $239-294$ & $268(5.54)$ & $208-345$ & $260(16.17)$ \\
\hline Fiber length $(\mu \mathrm{m})$ & $315-385$ & $346(5.95)$ & $275-360$ & $318(8.28)$ \\
\hline Ray density $\left(\right.$ per $\left.\mathrm{mm}^{2}\right)$ & $6.6-10.2$ & $8.7(13.8)$ & $6.5-7.1$ & $6.88(2.50)$ \\
\hline USR height $(\mu \mathrm{m})$ & $570-1107$ & $716(22.32)$ & $427-1240$ & $804.72(27.91)$ \\
\hline USR cell no & $6.6-22.7$ & $15.5(35.1)$ & $6.1-19.4$ & $9.65(46.87)$ \\
\hline
\end{tabular}

*Mean values of these parameters differed significantly between the two species.

Table 2: Results of t-test for comparing mean of wood characters between two species

\begin{tabular}{|l|c|c|c|}
\hline \multicolumn{1}{|c|}{ Parameters } & t value & Degree of freedom & Significance level (p) \\
\hline Pore density & 1.9 & 21.0 & 0.064 \\
\hline Pore area & -0.6 & 13.6 & 0.519 \\
\hline Vessel element length & 0.6 & 21.0 & 0.542 \\
\hline Fiber tracheid length & 2.9 & 21.0 & 0.008 \\
\hline Ray density & 5.1 & 11.4 & 0.000 \\
\hline UR height & -1.0 & 21.0 & 0.286 \\
\hline USR cell no & 2.7 & 21.0 & 0.011 \\
\hline
\end{tabular}

and their difference was not significant. Mean vessel element length was longer in $R$. anthopogon and their difference was not significant (Table 2). Fibers were longer than vessel elements. The mean FL of $R$. anthopogon $(347 \mu \mathrm{m})$ was significantly $(\mathrm{p}=0.008)$ higher than $R$. lepidotum $(318 \mu \mathrm{m})$ (Table 1 and 2). Mean ray density was higher in $R$. anthopogon and their difference was highly significant. Mean uniseriate ray height was higher in $R$. lepidotum (Table 1), and their difference was not significant (Table 2). The mean number of cells in uniseriate ray was higher in $R$. anthopogon and their difference was significant (Table 2).

The mean width of the multiseriate rays was higher in $R$. anthopogon than in $R$. lepidotum. The mean number of cells in tail of multiseriate rays was seven in $R$. anthopogon and eight in $R$. lepidotum. Though the multiseriate rays were not observed in all the samples of $R$. lepidotum, the height of multiseriate rays ranged between 225$1170 \mu \mathrm{m}$ in $R$. lepidotum and $180-1200 \mu \mathrm{m}$ in $R$. anthopogon. The number of cells in width of multiseriate rays was two to seven in both species.

Relations among anatomical and nonanatomical features

In $R$. anthopogon, plant height did not vary significantly with increasing elevation (Fig. 2). In $R$. lepidotum, out of three non- anatomical characters (plant height, nitrogen content in soil and leaf), plant height decreased with increasing elevation ( $\mathrm{P}=0.002$, Fig.2). The decrease in plant height of both Rhododendron species along the elevation gradient is a common phenomenon and could be interpreted as an adaptation to greater environmental stresses at higher elevation. Summer drought and winter cold are the main factors limiting plant growth in the Himalaya (Mitrakos, 1980). Both factors also affect the xylem structure (Fritts, 1976). In R. anthopogon, out of three non- anatomical characters (plant height, nitrogen content in soil and leaf); the nitrogen content in leaf was found 


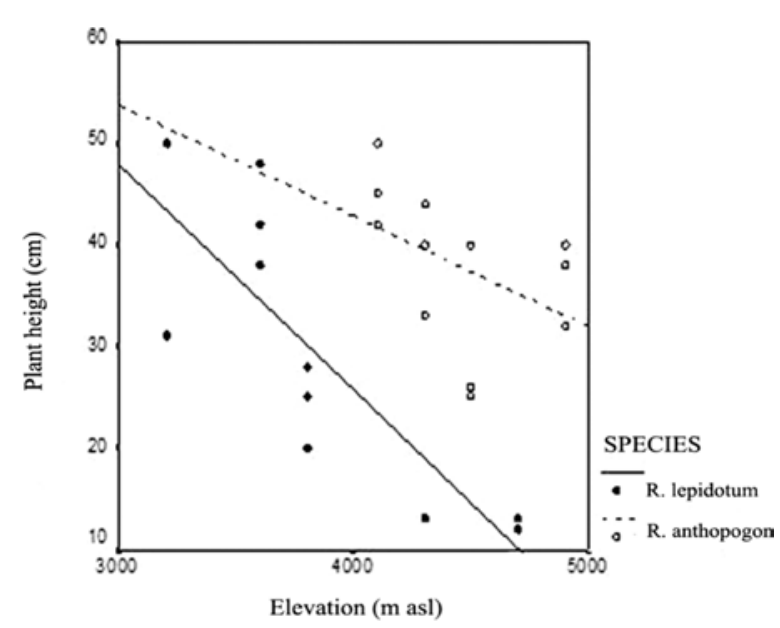

Fig. 2: Plant height along the elevational gradient $\left(R^{2}=0.20\right.$ and $P=0.147$ for $R$. anthopogon, and $R^{2}=0.68$ and $P=0.002$ for $R$. lepidotum)

to be increased along the altitudinal gradient and the relation was significant ( $\mathrm{P}=0.001$, Fig. 3 ). The increase in nitrogen content in leaf along the elevation gradient in $R$. anthopogon and $R$. lepidotum may be due to occurrence of the nutrients (nitrogen) more and for longer time in biomass of the plant species than in soil. In $R$. lepidotum, out of the seven anatomical wood characters, pore density and pore area decreased significantly $(\mathrm{P}=0.03)$ along the elevation gradient (Fig. 4 and Fig. 5). There was significant decrease in pore area, vessel element length and fiber tracheid length along the

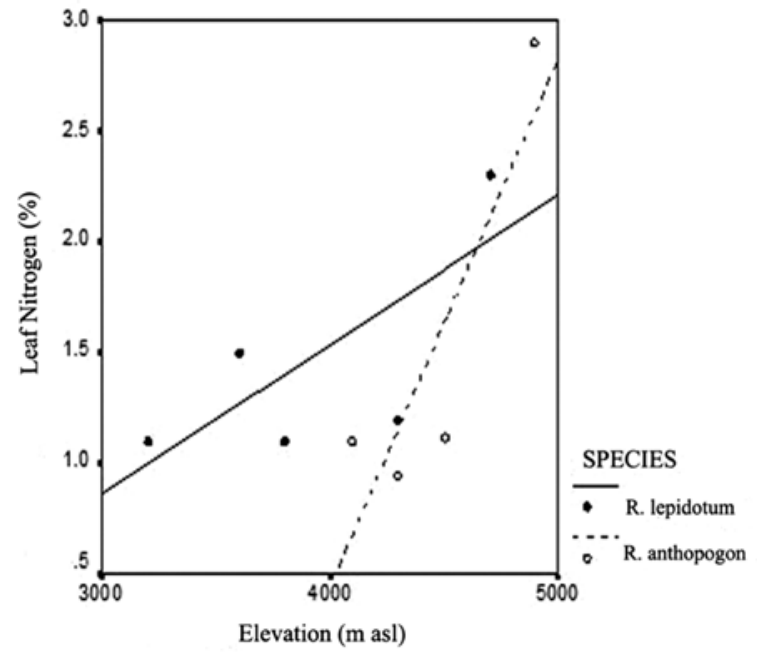

Fig. 3: Nitrogen content in leaf along the elevational gradient. $\left(R^{2}=\mathbf{0 . 7 7}\right.$ and $P=0.001$ for $R$. anthopogon and $R^{2}=0.568$ and $P=0.007$ for $R$. lepidotum)

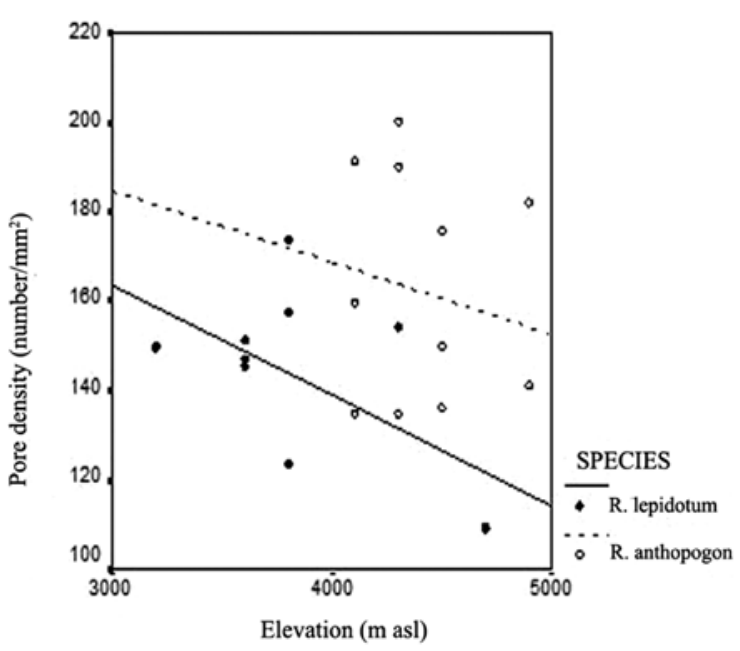

Fig. 4: Pore density along the elevational gradient. $\left(R^{2}=0.039\right.$ and $P=0.536$ for $R$. anthopogon and $R^{2}=0.39$ and $P=0.038$ for $R$. lepidotum)

elevation gradient for both species (Fig.5, 6 and 7). The other four characters such as, $\mathrm{PD}, \mathrm{RD}$, URH and URCN did not vary significantly with elevation. The correlation among nitrogen content in soil and leaf, all anatomical characters of both species with environmental factors (temperature and rainfall) were analysed. The positive significant relation of nitrogen content in soil and rainfall ( $\mathrm{P}=0.03$; Fig. 8$)$ are interrelated and might depend on nitrogen cycles in the habitat. The nitrogen content in soil can vary widely with litter

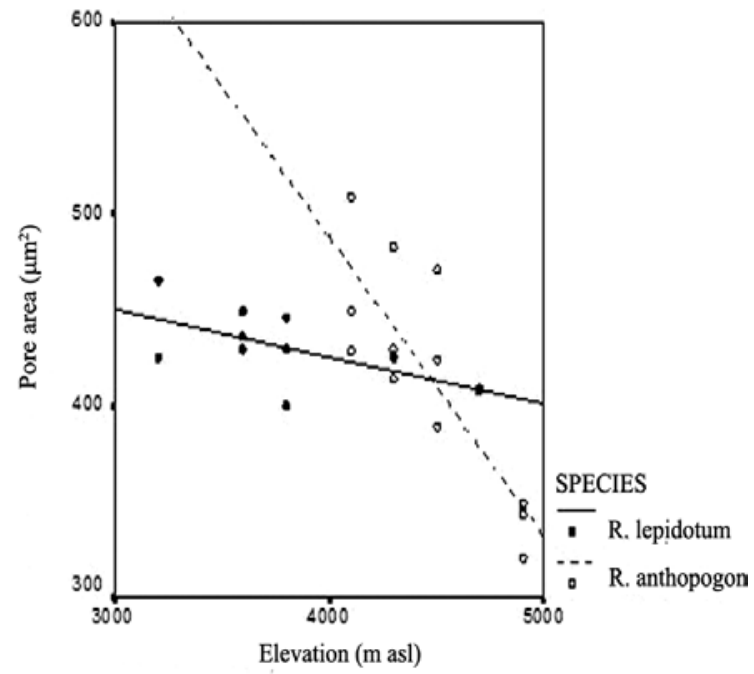

Fig. 5: Pore area along the elevational gradient. $\left(R^{2}=0.69\right.$ and $P=0.001$ for $R$. anthopogon and $R^{2}=0.41$ and $P=0.03$ for $R$. lepidotum) 


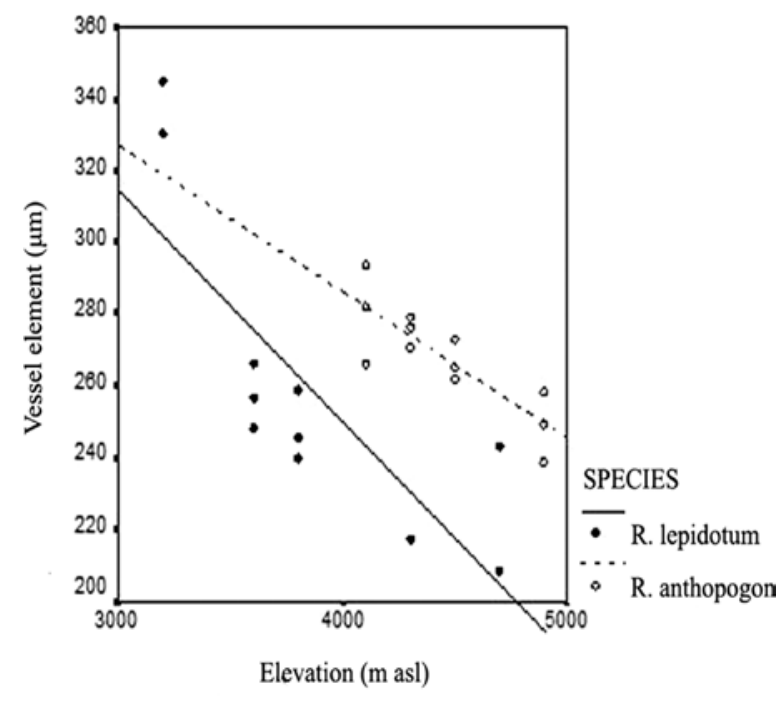

Fig. 6: Vessel element length along the elevational gradient. $\left(R^{2}=0.72\right.$ and $P=0.001$ for $R$. anthopogon and $R^{2}=0.64$ and $P=0.003$ for R. lepidotum)

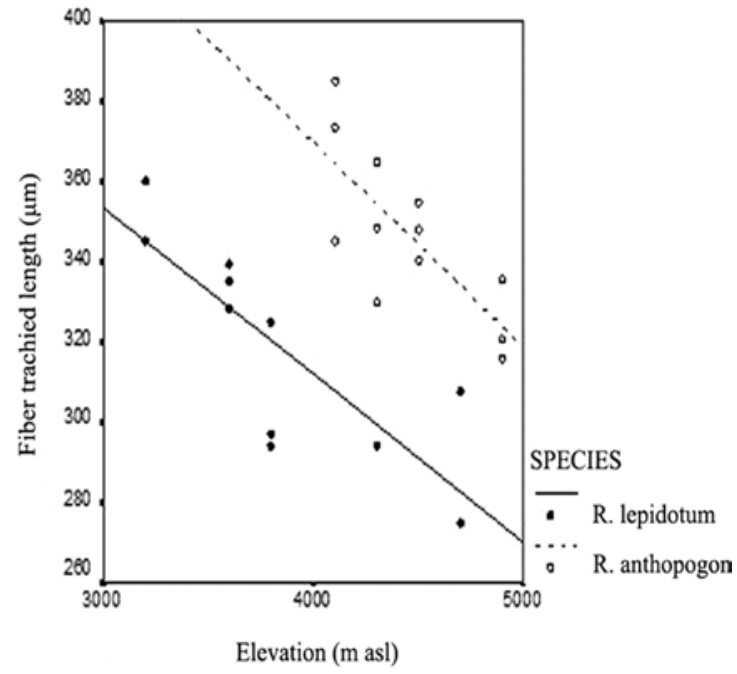

Fig. 7: Fiber tracheid length along the elevational gradient. $\left(R^{2}=0.78\right.$ and $P=0.004$ for $R$. anthopogon and $R^{2}=0.665$ and $P=0.002$ for $R$. lepidotum)

decomposition, effects of mesofauna, microclimate, rainfall, altitude and even slope position (Post et al.,1985; Garten et al.,1994; Enoki et al., 1997; Tateno and Takeda, 2003).

The positive significant relation was observed between nitrogen content in soil and rainfall ( $\mathrm{P}=0.03$; Fig. 8), rainfall along the elevation $(\mathrm{P}=0.008$; Fig. 9) and pore density with fiber length ( $\mathrm{P}=0.02$; Fig. 10). However, uniseriate ray height shows decreasing trend with increasing pore density ( $\mathrm{P}=0.01$; Fig. 11). Pore area of both Rhododendron species was found to be increased with increasing rainfall $(\mathrm{P}=0.04$; Fig. 12) and higher vessel element length was observed with increasing leaf nitrogen $(\mathrm{P}=0.02$; Fig. 13).

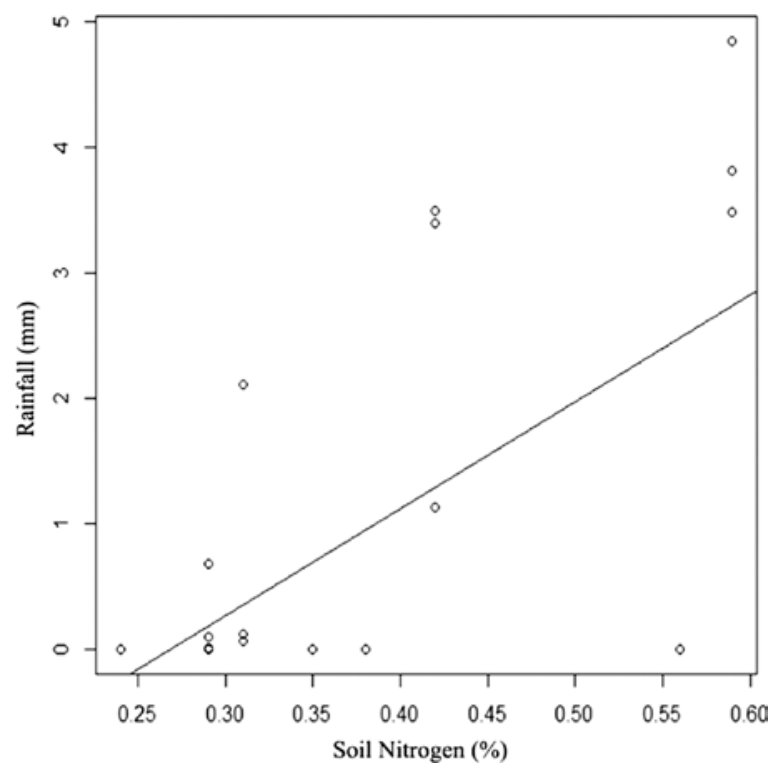

Fig. 8: The relation between rainfall and soil nitrogen ( $\mathrm{P}=\mathbf{0 . 0 3}$ for both species)

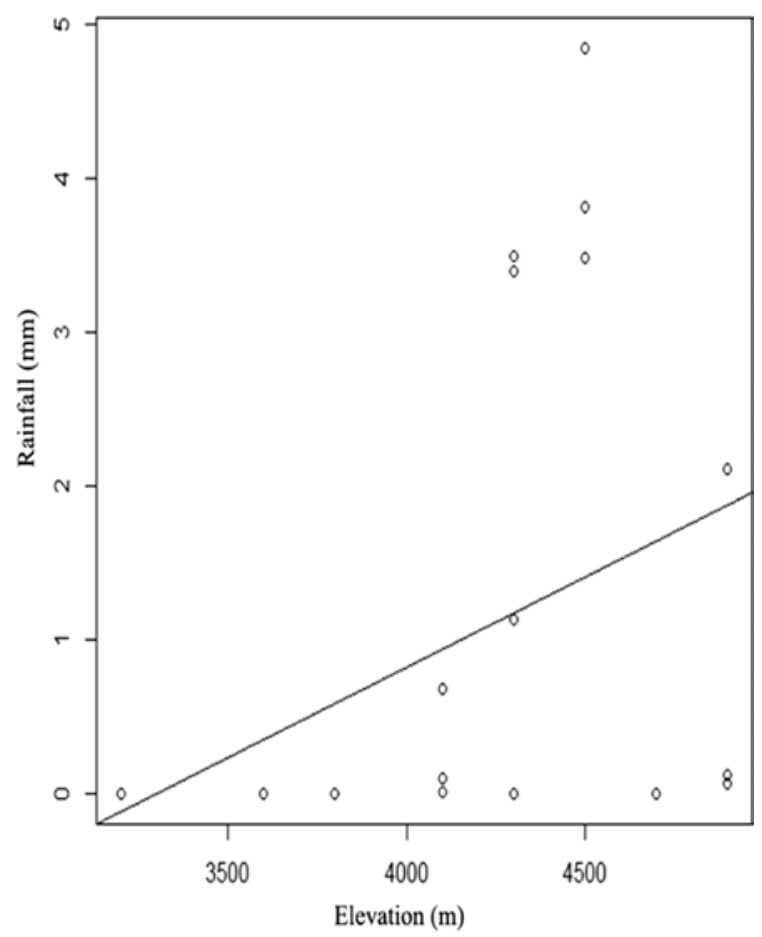

Fig. 9: The relation of rainfall along the elevation ( $\mathrm{P}=\mathbf{0 . 0 0 8}$ for both species) 


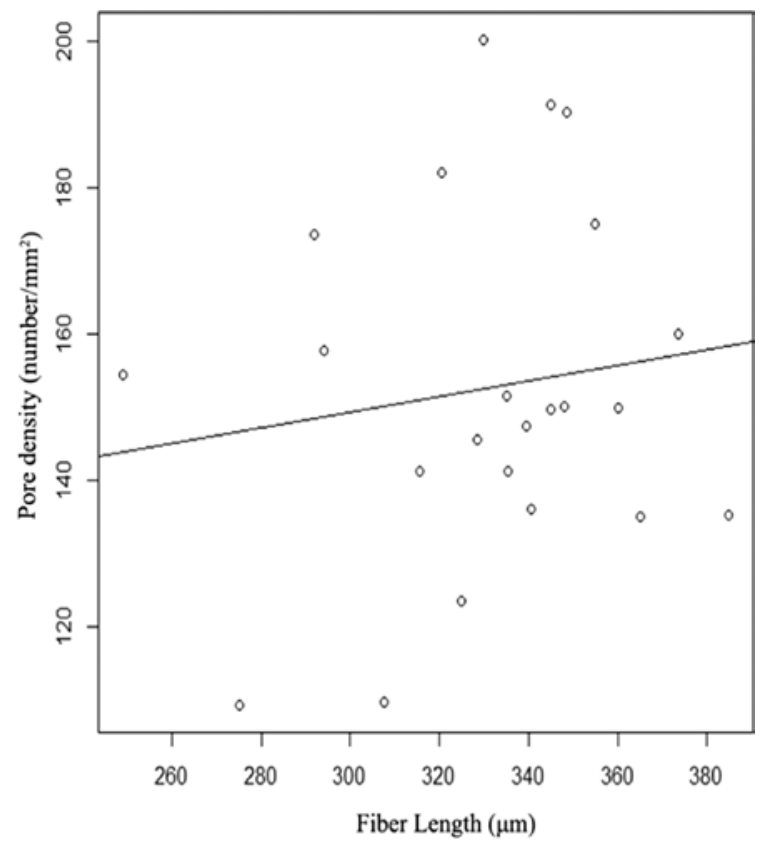

Fig. 10: The relation of pore density with fiber length( $\mathrm{P}=0.02$ for both species)

Length of vessel elements as well as fibers declined with increasing elevation in $R$. lepidotum and $R$. anthopogon (Noshiro and Suzuki, 2001; Fig. 6 and 7). A decrease in the mean diameter of

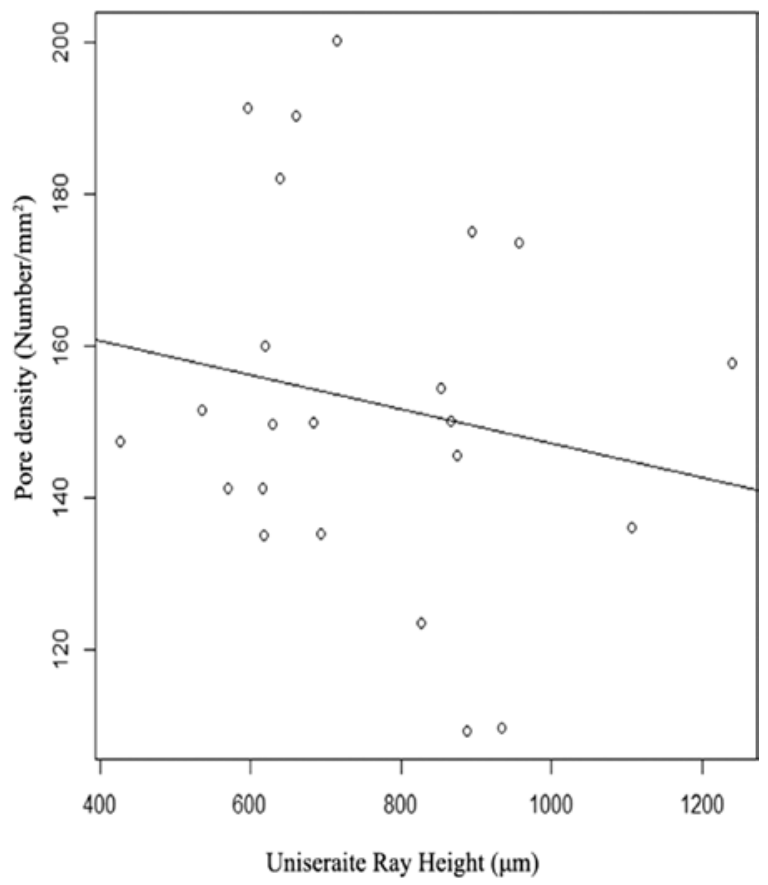

Fig. 11: The relation of pore density with uniseriate ray height $(P=0.01$, for both species $)$

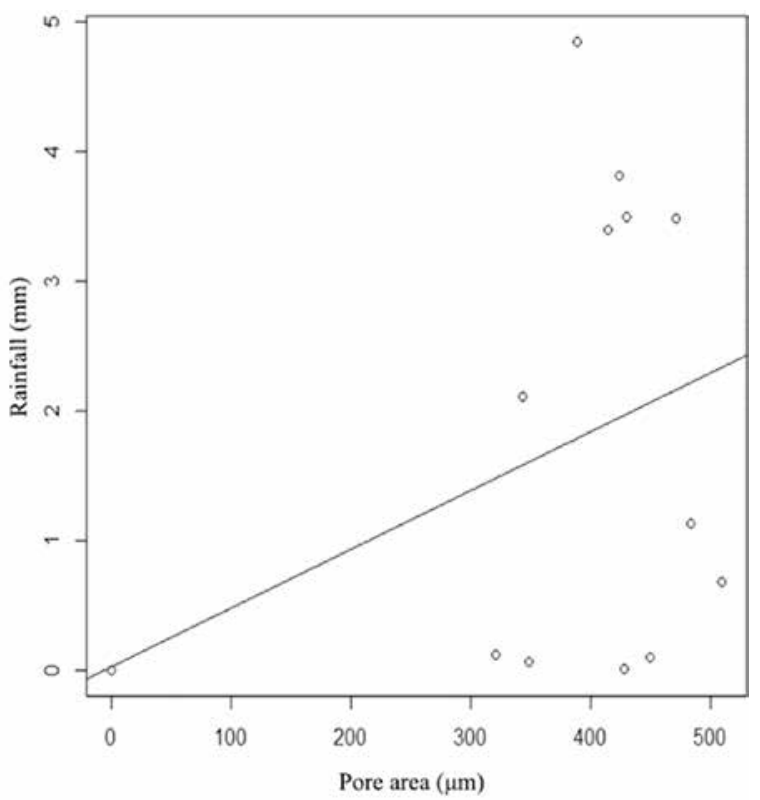

Fig. 12: The relation of rainfall with pore area ( $P=0.04$, for both species)

the conduits (tracheids and vessels) have been associated with a reduction of water availability in the soil or lower temperature (Carlquist, 1975; Baas et al., 1983). Altitude appears to be an important factor governing the wood anatomical variation in Rhododendron. More than a dozen

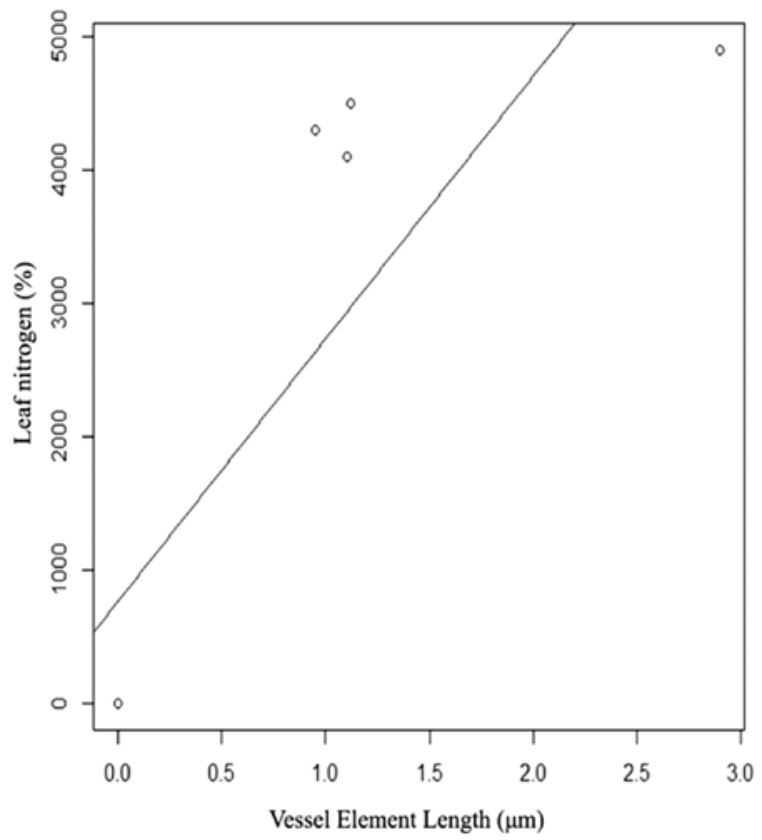

Fig. 13: The relation of leaf nitrogen with vessel element length ( $\mathrm{P}=\mathbf{0 . 0 2}$, for both species) 
of wood anatomical features of 26 Rhododendron species varied significantly with altitude (Noshiro et al., 1995). Some variation in wood anatomical features has been attributed to the adaptive strategies of the plant in the hostile environment at high elevation (Noshiro and Suzuki, 2001). Decline in length of vessel elements and fiber has also been reported for Ilex species, and many other widespread genera (Baas et al., 1983). However, ray density, uniseriate ray height and number of cells per uniseriate ray did not vary significantly along the elevation $(\mathrm{P}>0.05)$.

\section{Nitrogen content in soil and leaf}

The nitrogen content in leaf of $R$. anthopoggon and $R$. lepidotum was higher than nitrogen content in soil (Table 3). The t-test showed that there was no significant difference in mean nitrogen content in soil between two species while there was significant difference in mean nitrogen content in leaf between two species (Table 4).

The principal component analysis shows the important presence of elevation, habit and temperature, plant height, vessel length, ray density and pore density with Eigen values greater than 0.5 (Table 5; Fig.14).

Table 3: Nitrogen content in soil and leaf

\begin{tabular}{|l|l|l|l|l|}
\hline \multirow{2}{*}{$\begin{array}{l}\text { Soil and } \\
\text { Leaf } \mathrm{N}_{2}\end{array}$} & \multicolumn{3}{|c|}{ R anthopogon } & \multicolumn{1}{|c|}{$\begin{array}{c}\text { R. } \\
\text { lepidotum }\end{array}$} \\
\cline { 2 - 5 } & $\begin{array}{c}\text { Range } \\
(\mathrm{mg} / \mathrm{kg})\end{array}$ & $\begin{array}{l}\text { Mean } \\
(\mathrm{CV}), \%\end{array}$ & $\begin{array}{l}\text { Range } \\
(\mathrm{mg} / \mathrm{kg})\end{array}$ & $\begin{array}{l}\text { Mean } \\
(\mathrm{CV}), \%\end{array}$ \\
\hline Soil $\mathrm{N}_{2}(\%)$ & $\begin{array}{l}0.29- \\
0.59\end{array}$ & $\begin{array}{l}0.40 \\
(31.32)\end{array}$ & $\begin{array}{l}0.23- \\
0.56\end{array}$ & $0.37(28.71)$ \\
\hline Leaf $_{2}(\%)$ & $0.95-2.90$ & $1.51(8.77)$ & $1.10-2.30$ & $1.43(16.61)$ \\
\hline
\end{tabular}

Table 4: Results of t-test for comparing mean of nitrogen content in soil and leaf in two species

\begin{tabular}{|l|c|c|c|}
\hline Parameters & $\begin{array}{c}\mathbf{t} \\
\text { value }\end{array}$ & $\begin{array}{c}\text { Degree of } \\
\text { freedom }\end{array}$ & $\begin{array}{l}\text { Significance } \\
\text { level (p) }\end{array}$ \\
\hline Soil $\mathrm{N}_{2}$ & 0.7 & 21.0 & 0.487 \\
\hline Leaf $\mathrm{N}_{2}$ & -3.3 & 13.3 & 0.005 \\
\hline
\end{tabular}

Table 5: Principal component analysis (PCA)
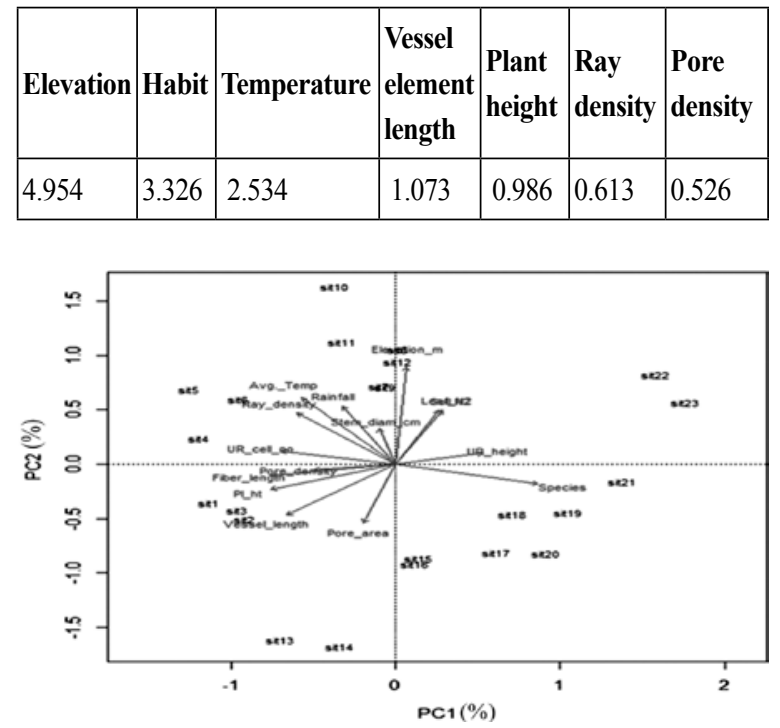

Fig. 14: Principal component analysis among all anatomical and environmental characters for Rhododendron species

Among the seven wood anatomical characters in $R$. anthopogon, there was a positive correlation between pore area and vessel element length, ray density and number of cells in uniseriate rays $(\mathrm{P}=0.009)$, vessel element length and fiber tracheid length $(\mathrm{P}=0.003)$. There was a negative correlation between the ray density and uniseriate ray height $(\mathrm{P}=0.003)$, and uniseriate ray height and uniseriate ray cell number (Table 6).

Table 6: Correlations among different wood parameters of $R$. anthopogon $(n=12)$

\begin{tabular}{|l|c|c|c|c|c|c|}
\hline Parameters & $\begin{array}{c}\text { Pore } \\
\text { density }\end{array}$ & $\begin{array}{c}\text { Pore } \\
\text { area }\end{array}$ & $\begin{array}{c}\text { Vessel } \\
\text { element } \\
\text { length }\end{array}$ & $\begin{array}{c}\text { Fiber } \\
\text { length }\end{array}$ & $\begin{array}{c}\text { Ray } \\
\text { density }\end{array}$ & $\begin{array}{c}\text { Uniseriate } \\
\text { ray height }\end{array}$ \\
\hline Pore area & 0.34 & & & & & \\
\hline Vessel element length & 0.10 & $0.60^{*}$ & & & & \\
\hline Fiber length & -0.28 & 0.40 & $0.78^{* *}$ & & & \\
\hline Ray density & 0.12 & -0.23 & -0.10 & -0.18 & & \\
\hline Uniseriate ray height & -0.17 & 0.30 & 0.80 & 0.05 & $-0.77^{* *}$ & \\
\hline Uniseriate ray cell no & 0.21 & -0.14 & 0.09 & -0.15 & $0.94^{* *}$ & $-0.71^{* *}$ \\
\hline
\end{tabular}

* Correlation is significant at the 0.05 level (2-tailed). ${ }^{* *}$ Correlation is significant at the 0.01 level (2-tailed). ( $\mathrm{N}=$ Number of samples) 
In $R$. lepidotum, among the seven wood anatomical characters, positive correlation was found between vessel element length and fiber length $(\mathrm{P}=0.01)$ and vessel element length and number of cells in uniseriate ray $(\mathrm{P}=0.001)$. There was negative correlation between vessel element length and ray density $(\mathrm{P}=0.04)$, vessel element length and number of uniseriate ray cell $(\mathrm{P}=0.001)$, fiber length and ray density and uniseriate ray height (Table 7)

Table 7: Correlations among different wood parameters of $R$. lepidotum $(\mathrm{n}=11)$

\begin{tabular}{|l|c|c|c|c|c|c|}
\hline Attributes & $\begin{array}{c}\text { Pore } \\
\text { density }\end{array}$ & Pore area & $\begin{array}{c}\text { Vessel } \\
\text { element } \\
\text { length }\end{array}$ & $\begin{array}{c}\text { Fiber } \\
\text { length }\end{array}$ & $\begin{array}{c}\text { Ray } \\
\text { density }\end{array}$ & $\begin{array}{c}\text { Uniseriate } \\
\text { ray height }\end{array}$ \\
\hline Pore area & 0.46 & & & & & \\
\hline Vessel element length & 0.35 & 0.53 & & & & \\
\hline Fiber length & 0.21 & 0.58 & $0.72^{*}$ & & & \\
\hline Ray density & -0.48 & -0.05 & $-0.62^{*}$ & $-0.62^{*}$ & & \\
\hline Uniseriate ray height & -0.04 & $-0.69^{*}$ & -0.44 & $-0.70^{*}$ & 0.13 & \\
\hline Uniseriate ray cell no & 0.06 & 0.23 & $0.85^{* *}$ & 0.56 & -0.52 & -0.17 \\
\hline
\end{tabular}

* Correlation is significant at the 0.05 level (2-tailed). ** Correlation is significant at the 0.01 level (2-tailed). ( $\mathrm{N}=$ Number of samples)

Some other research also revealed that the decreasing size and diameter of vessel along the elevation indicating that vessel diameter is determined both by genotype (parental population) and environmental factors (Fisher et al., 2007). The data of all measured anatomical and environmental parameter is given in Annex 1.

\section{Conclusions}

The anatomical differences between the $R$.anthopogon and $R$. lepidotum were less prominent. Variation in vessel and pore characters along elevation gradient reveals that vessels, fiber and tracheid play important role to adopt in harsh environment. Though important presence of elevation, temperature and plant height was observed by PCA, however, only on the basis of this could not be explained adaptive strategy of anatomical features.

\section{Acknowledgements}

We are very much grateful to Hindu KushKarakoram-Himalaya (HKKH) Partnership Project (EvK2-CNR, Italy) for research grant to Pramod Kumar Jha. We acknowledge the Chief of National Herbarium and Plant Laboratories (NHPL) at that time for administrative support in anatomical study at National Herbarium and Plant Laboratory, Godawari, Lalitpur. We also thank S Noshiro and M Suzuki for providing relevant literatures.

\section{References}

Bass, P., Werker, E. and Fahn, A. 1983. Some ecological trends in vessel characters. International Association of Wood Anatomists Bulletin 4: 141-159.DOI: $\quad 10.1163 / 22941932-$ 90000407 .

Bhuju, U. R., Shakya, P. R., Basnet,T. B. and Shresha,S. 2007. NepalBiodiversity Resource Book: Protected Areas, Ramsar Sites and World Heritage Sites. Kathmandu:ICIMOD.

Carlquist, S 1975. Wood Anatomy and Relationships of Geissolomataceae. Bulletin of the Torrey Botanical Club 102 (3): 128-134.

Chamberlain, D., Hyam, R., Argent, G., Fairweather, G. and Walter, K. S.1996. The Genus Rhododendron, Its Classification and Synonymy. Royal Botanic Garden, Edinburgh.

Garratt, K. 1981. Sagarmatha National Park Management Plan. HMG/New Zealand Cooperation Project. Department of Lands and Survey, Wellington, New Zealand.

Enoki, T., Kawaguchi, H. and Iwatsubo, G. 1997. Nutrient-uptake and nutrient-use efficiency of Pinus thunbergii Parl. along a topographical gradient of soil nutrient availability. Ecol Res 
12:191-199.

Gupta, P. K. 2000. Methods in Enviromental Analysis: Water Soil and Air. Agrobios, New Delhi, India.

Fritts, H. C. 1976. Tree Ring and Climate. Academic press, New York, USA.

Fisher, J. B., Goldstein, G., Jones, T. J. and Cordell, S. 2007. American Journal of Botany. Wood vessel diameter is related to elevation and genotype in the Hawaiian tree metrosideros polymorpha ( Myrtaceae). 94 (5):709-715. DOI: 10.3732/ajb.94.5.709.

Farquhar, G. D., Ehleringer, I. J. R. and Hubick, K. T. 1989. Carbon isotope discrimination and photosynthesis. Annu. Rev. Plant Physiol. Plant Mol. Biol. 40: 503-537.

Garten, C. T., Huston, M. A. and Thoms, C. A. 1994. Topographic variation of soil nitrogen dynamics at Walker Branch watershed, Tennessee. For Sci 40: 497-512.

Jha, P. K. 2010. Contemporary Research in Sagarmatha (Mt. Everest) Region, Nepal. Nepal Academy of Science and Technology (NAST). Khumaltar, Lalitpur, Nepal.

Joshi, D. 1982. The climate of Namche Bazar: a bioclimatic analysis. Mountain Research and Development 2: 399-403.

Keer, J. 2001. Global biodiversity patterns: from description to understanding. Ecology and Evolution 16: 424-425. DOI: http://dx.doi. org/10.1016/S0169-5347(01)02226-1

Kramer, P. J. and Kozlowski, T. T. 1979. Physiology of Woody Plants. Academic Press, New York, USA.

Liang, C. B., Bass, P., Wheeler, E. and Shuming, W. 1993. Wood anatomy of trees and shrubs from China. VI. Magnoliaceae. IAWA 14 (4): 391-412. DOI: 10.1163/2294193290000594

Levitt, J. 1972. Response of Plants to Environmental Stresses. Academic Press, New York, USA..

Mitrakos, K. A. 1980. A theory for Mediterranean plant life. Acta Oecol. 1: 245-252.
Noshiro, S. and Suzuki, M. 1989. Altitudinal distribution and tree form of Rhododendron in the Barun Valley, East Nepal. J. Phytogeogr. and Taxon. 37: 121-127.

Noshiro, S., Suzuki, M. and Ohba, H. 1995. Ecological wood anatomy of Nepalese Rhododendron (Ericaceae): 1 Inter- specific variation. Journal of Plant Research 108:19. DOI:10.1007/BF02344347

Noshiro, S. and Baas, P. 1998. Systematic wood anatomy of cornaceae and allies. IAWA 19 (1): 43-97. DOI: 10.1163/2294193290000652

Noshiro, S. and Baas, P. 2000. Latitudinal trends in wood anatomy within species and genera: case study in Cornuss.l. (Cornaceae). American Journal of Botany 87 (10):14951506. DOI: $10.2307 / 2656876$

Noshiro, S. and Suzuki, M. 2001. Ontogenetic wood anatomy of tree and subtree species of Nepalese Rhododendron (Ericaceae) and characterization of shrub species. Amrican Journal of Botany 88 (4): 560-569.DOI: $10.2307 / 2657054$.

Post, W. M., Pastor, J.,Zinke,P. J. and Stangenberger, A. G. 1985. Global patterns of soil nitrogen storage. Nature 317 (6038): 613-616.

Rajbhandari, K. R. and Watson, M. 2005. Rhododendrons of Nepal. Fascicle of Flora of Nepal 5 (6).

Shrestha, B. B. and Jha, P. K. 2010. Rhododendrons in Sagarmatha National Park, Nepal. In Contemporary Research in Sagarmatha (Mt. Everest) Region,Nepal (eds.) Jha, P. K. and Khanal, I . Nepal Academy of Science and Technology (NAST), Lalitpur, Nepal, 189198.

Tateno, R. and Takeda, H. 2003. Forest structure and tree species distribution in relation to topography mediated heterogeneity of soil nitrogen and light at forest floor. Ecol Res 18: 559-571. 


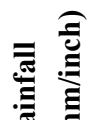

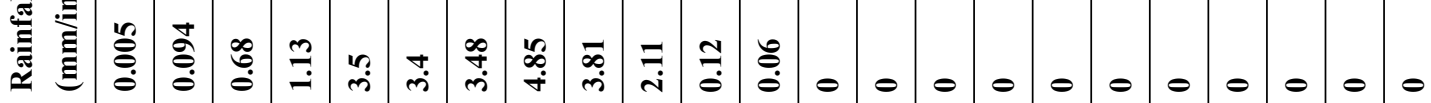
童 $\tilde{z}_{1}$

焉 $\tilde{z}$

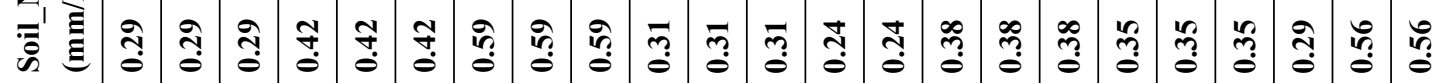
z

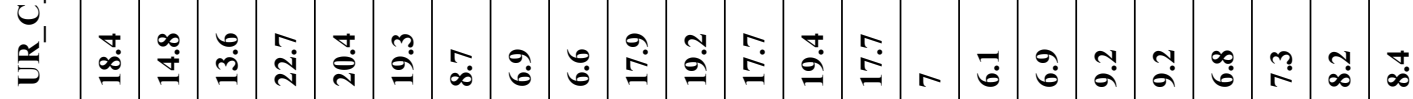
吉害 สิ

$\theta_{1}$

至

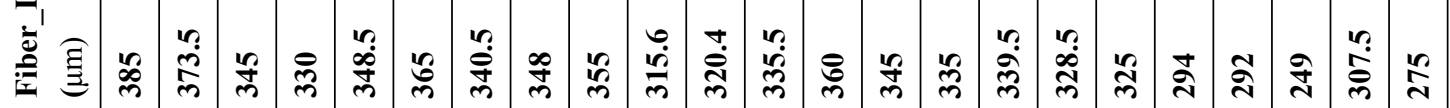

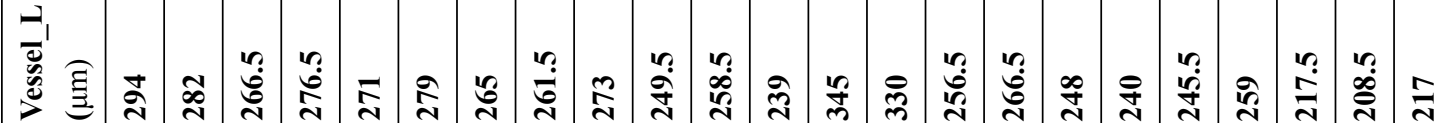
४

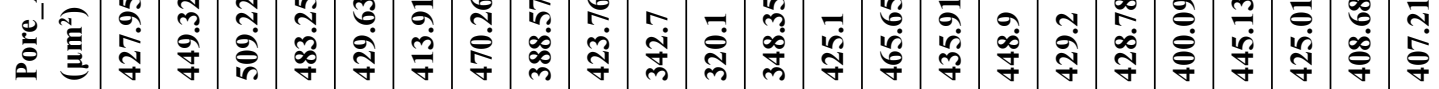
节

$\theta_{1}$

总 气્

离 莣

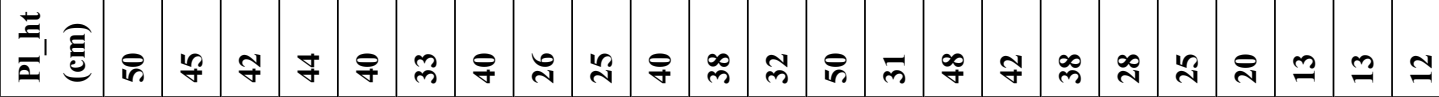

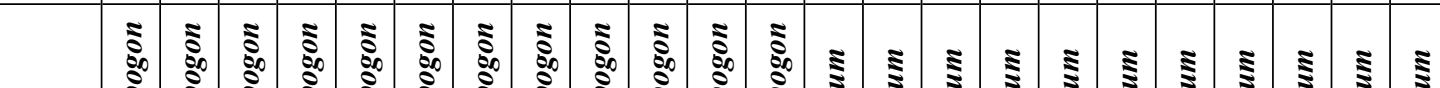

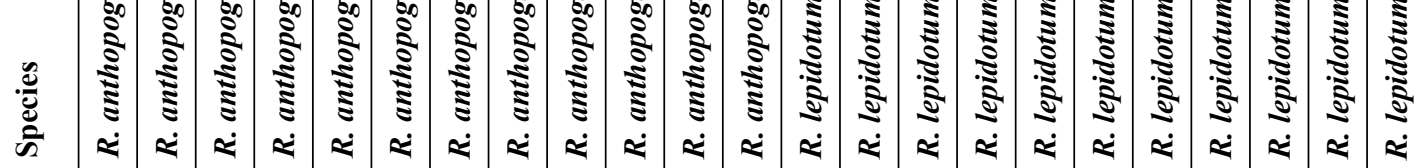


Annex 2: Plates of different species of Rhododendron
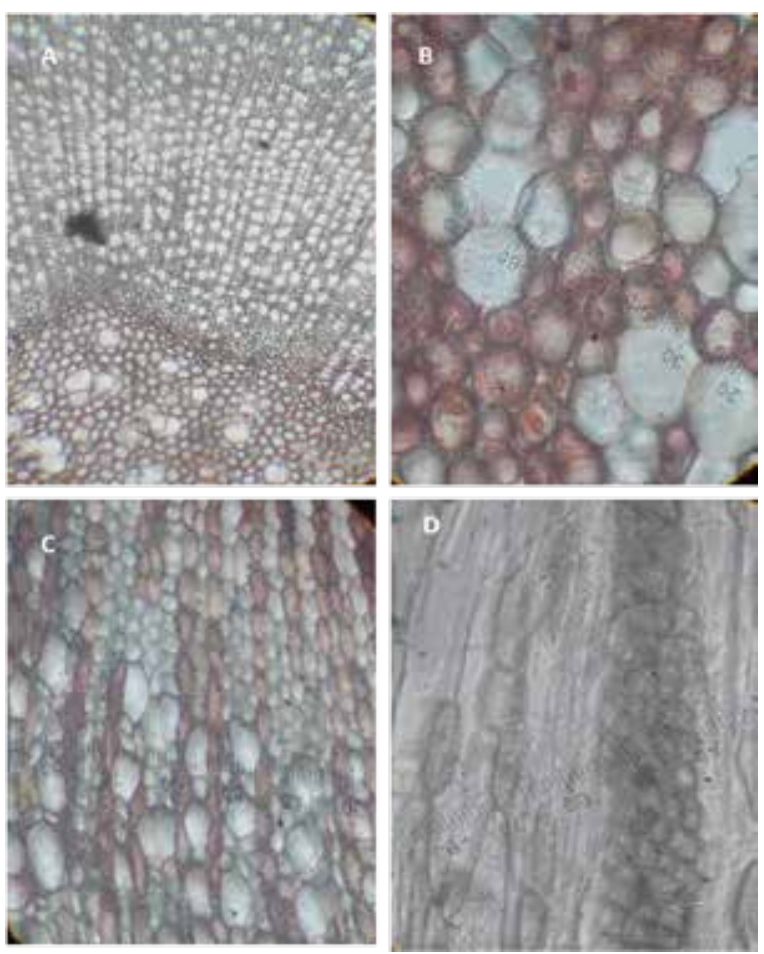

Plate 1 (A-D) :Rhododendron lepidotum; A: TS of stem showing pith and vessels $(15 \times 10)$, B) TS showing pith $(15 \times 40)$, C) TLS showing uniseriate rays $(15 \times 40)$, and D) TLS showing both uniseriate and multiseriate rays $(15 \times 40)$
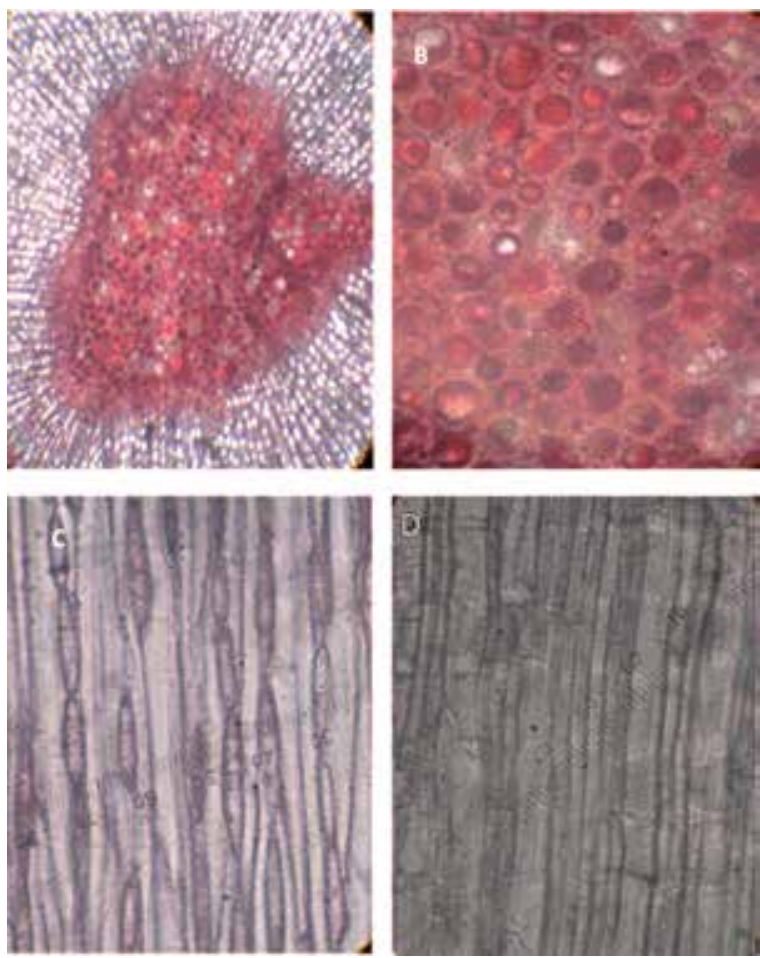

Plate 2 (A-D) Rhododendron anthopogon; A) TS of stem showing pith $(15 \times 10)$, B) TS showing pith with crystals $(15 \times 40)$, C) TLS showing uniseriate rays $(15 \times 40)$, and D) RLS of $R$. anthopogon $(15 \times 40)$
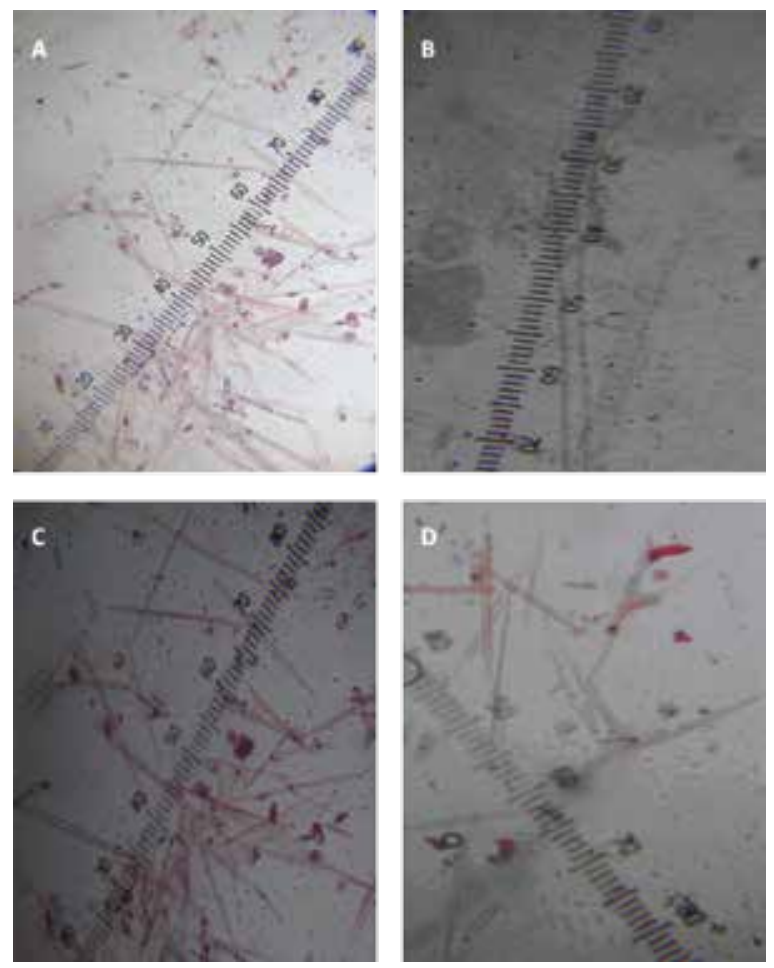

Plate 3 (A-D): Rhododendron anthopogon; A) vessels and fibers $(15 \times 40), \mathrm{C}, \mathrm{D})$ Rhododendron lepidotum - vessels and fibers $(15 \times 40)$ 